\title{
Fundamentals of Value versus Growth Investing and an Explanation for the Value Trap
}

\author{
Penman, Stephen ; Reggiani, Francesco
}

\begin{abstract}
Value stocks earn higher returns than growth stocks on average, but a "value" position can turn against the investor. Fundamental analysis can explain this so-called value trap: The investor may be buying earnings growth that is risky. Both the earnings-to-price ratio $(\mathrm{E} / \mathrm{P})$ and the book-to-price ratio $(\mathrm{B} / \mathrm{P})$ come into play. $\mathrm{E} / \mathrm{P}$ indicates expected earnings growth, but price in that ratio also discounts for the risk to that growth; $\mathrm{B} / \mathrm{P}$ indicates that risk. A striking finding emerges: For a given $\mathrm{E} / \mathrm{P}$, a high $\mathrm{B} / \mathrm{P}$ ("value") indicates higher expected earnings growth-but growth that is risky. This finding contrasts with the standard convention that considers a low B/P to be "growth" with lower risk.
\end{abstract}

DOI: https://doi.org/10.2469/faj.v74.n4.6

Posted at the Zurich Open Repository and Archive, University of Zurich ZORA URL: https://doi.org/10.5167/uzh-173225

Journal Article

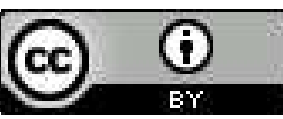

The following work is licensed under a Creative Commons: Attribution 4.0 International (CC BY 4.0) License.

Originally published at:

Penman, Stephen; Reggiani, Francesco (2018). Fundamentals of Value versus Growth Investing and an Explanation for the Value Trap. Financial Analysts Journal, 74(4):103-119.

DOI: https://doi.org/10.2469/faj.v74.n4.6 


\title{
Fundamentals of Value vs. Growth Investing and an Explanation for the Value Trap
}

\author{
Stephen Penman* \\ Professor, Columbia Business School, Columbia University \\ shp38@columbia.edu
}

Francesco Reggiani

Assistant Professor, Department of Business Administration, University of Zürich francesco.reggiani@business.uzh.ch

This paper had an earlier title, "The Value Trap: Value Buys Risky Growth"

It is forthcoming in the Financial Analysts Journal

July 2018

*Corresponding author. Address: Columbia Business School, 612 Uris Hall, 3022 Broadway, New York, NY 10027.

Acknowledgments. The authors thank reviewers for helpful comments.

Disclosure: The authors report no conflict of interest 


\title{
Fundamentals of Value vs. Growth Investing and an Explanation for the Value Trap
}

\begin{abstract}
Value stocks earn higher returns than growth stocks on average, but a "value" position can turn against the investor. Fundamental analysis can explain this so-called value trap: the investor may be buying earnings growth that is risky. Both $\mathrm{E} / \mathrm{P}$ and $\mathrm{B} / \mathrm{P}$, come into play: $\mathrm{E} / \mathrm{P}$ (or $\mathrm{P} / \mathrm{E}$ ) indicates expected earnings growth, but price in that ratio also discounts for the risk to that growth; $\mathrm{B} / \mathrm{P}$ indicates that risk. A striking finding emerges: for a given $\mathrm{E} / \mathrm{P}$, high $\mathrm{B} / \mathrm{P}$ ("value") is indicates higher expected earnings growth, but growth that is risky. This contrasts with the standard labeling that nominates low B/P as "growth" with lower risk.
\end{abstract}

Keywords: Value and Growth Investing; Value Trap; Growth and Risk 


\section{Fundamentals of Value vs. Growth Investing and an Explanation for the Value Trap}

"Value" and "growth" are prominent labels in the lexicon of finance. They refer to investing styles that buy firms with low multiples ("value") versus high multiples ("growth"), though the labels sometimes simply refer to buying low price-to-book versus high price-to-book. "Value" is sometimes taken to indicate a "cheap" stock, and history informs that value outperforms growth on average. However, a value position can turn against the investor, and therein lies the value trap. Indeed, experience with value stocks in the last few years has been sobering. Despite the prominence of these styles, it is not clear what one is buying with value and growth stocks, and the labels are not particularly illuminating.

This paper supplies the understanding in terms of the underlying fundamentals. ${ }^{1}$ When one buys a stock, one buys future earnings. Accordingly, price multiples imbed expectations of earnings growth; indeed, it is well-recognized that the earnings-to-price (E/P) ratio (or the P/E ratio) indicates the market's expectation of future earnings growth. However, less wellrecognized, growth can be risky — it may not be realized — so price (in the E/P ratio) discounts for that risk. Understanding the exposure to this risk is thus key to an investor buying growth in an $\mathrm{E} / \mathrm{P}$ ratio. The paper shows that book-to-price $(\mathrm{B} / \mathrm{P})$ also indicates growth but also the risk in

\footnotetext{
${ }^{1}$ The paper draws on Penman and Reggiani (2013), Penman, Reggiani, Richardson, and Tuna (2018), and Penman and Zhang (2018), papers that connect earnings growth to risk. The paper takes the ideas and some empirical results in those papers to the issue of value vs. growth investing.
} 
buying that growth: for a given $\mathrm{E} / \mathrm{P}$, a high $\mathrm{B} / \mathrm{P}$ indicates a higher likelihood that growth will not be realized. While a high $\mathrm{B} / \mathrm{P}$ stock might look cheap, that could be a trap.

A unifying theme underlies the analysis: pricing ratios, like $\mathrm{E} / \mathrm{P}$ and $\mathrm{B} / \mathrm{P}$, involve accounting numbers; given price, they are accounting phenomena, a construction of the accounting involved. Thus, one understands the risk in buying $\mathrm{E} / \mathrm{P}$ and $\mathrm{B} / \mathrm{P}$ by understanding the accounting that generates earnings and book value. These accounting principles, involving the realization principle and conservative accounting for investment, are familiar to the student of a basic accounting course. The paper applies them to understanding investing risk.

Three points emerge from the paper. First, E/P and B/P are multiples to be employed together. Just as earnings and book value-the "bottom line" numbers in the income statement and balance sheet—articulate in accounting sense, so do $\mathrm{E} / \mathrm{P}$ and $\mathrm{B} / \mathrm{P}$ articulate to convey risk and the expected return for that risk. Second, when applied jointly with $\mathrm{E} / \mathrm{P}$, high $\mathrm{B} / \mathrm{P}-$ a value stock-indicates higher future earnings growth. This is surprising, for the standard labeling implies that it is "growth" (a low B/P) that buys growth, not "value." Third, the higher growth associated with high $\mathrm{B} / \mathrm{P}$ is risky: high $\mathrm{B} / \mathrm{P}$ stocks are subject to more extreme shocks to growth. These are empirical findings but the paper demonstrates that they are also properties implied by the accounting for earnings and book value.

The analysis explains some puzzling features observed in value vs. growth investingwhy buying B/P predicts returns for small firms but not large firms, and why, for large firms, E/P dominates $\mathrm{B} / \mathrm{P}$ in predicting returns. These differences are explained by relative exposure to growth at risk, an exposure indicated by the accounting fundamentals. Indeed, returns to investing by firm size can be explained by exposure to risky growth. 
We are not the first to associate the value-growth spread with fundamentals, of course.

Fama and French (1995), for example, show that high B/P is associated with low profitability, and Cohen, Polk, and Vuolteenaho (2009) and Campbell, Polk, and Vuolteenaho (2010) calibrate the risk with fundamental ("cash-flow") betas. ${ }^{2}$ The aim here is not just to add more evidence on the risk in value stocks. Rather, it is to explain why. We show why value connects to low profitability and why that connection implies the risky outcomes documented in these papers.

First, we document the historical returns to value versus growth investing — returns that the subsequent analysis then explains.

\section{Returns to Value versus Growth Investing}

Panel A of Table 1 reports the average annual returns to investing on the basis of $\mathrm{E} / \mathrm{P}$ and $\mathrm{B} / \mathrm{P}$ during the years 1963-2015. The sample covers all firms on Compustat at any time during those years, except financial firms (SIC codes 6000-6999), firms with negative book values, and firms with per-share stock prices less the $\$ 0.20$. Earnings and book value of common equity are from Compustat. Prices for the multiples are those three months after fiscal-year end at which time accounting numbers for the fiscal year should have been reported (as required by law). Like earnings and book value, prices are per-share, adjusted for stock splits and stock dividends over the three months after fiscal-year end. Annual returns are observed over the 12 months after this date, calculated as buy-and-hold returns from monthly returns on CRSP with an accommodation

\footnotetext{
${ }^{2}$ In addition, La Porta, Lakonishok, Shleifer, and Vishny (1997) report that the value-growth spread over the three days surrounding quarterly earnings announcements accounts for about 30 percent of the annual return spread. Doukas, Kim, and Pantzalis (2002 and 2004) test whether the return spread is due to bias in analysts' earnings forecasts (it is not) and related to risk indicated by higher dispersion of analysts' forecast for value stocks (it is). Piotroski and So (2012) indicate that return differences for value versus growth firms is concentrated in firms where market expectations differ from those indicated by a fundamental scoring metric.
} 
for firms not surviving the full 12 months. A total of 176,848 firm-year observations are involved. $^{3}$

Table 1 is constructed as follows. Each year, firms are ranked on their E/P ratios and formed into five portfolios from low to high $\mathrm{E} / \mathrm{P}$ (along the top row in the panels). Then, within each $\mathrm{E} / \mathrm{P}$ portfolio, firms are the ranked on their $\mathrm{B} / \mathrm{P}$ and formed into five portfolios (down the columns). This nested sort ensures that the $\mathrm{B} / \mathrm{P}$ sort is for firms with a similar portfolio E/P. E/P portfolio 1 is all loss firms. ${ }^{4}$

The first row in Panel A reports equally-weighted returns (before transaction costs) for $\mathrm{E} / \mathrm{P}$ portfolios before ranking on $\mathrm{B} / \mathrm{P}$. E/P ranks returns, and monotonically so for positive E/P portfolios 2-5, as is well-known (and documented in Basu 1977 and 1983 and Jaffe, Keim, and Westerfield 1989, for example). Further, for a given E/P, B/P ranks returns (down columns): the "book-to-price" effect in stock returns in evident, but now for stocks with a given E/P. The mean return spread between the $1.9 \%$ return for the low-E/P and low-B/P portfolio and the $27.1 \%$ return for the high-E/P and high-B/P portfolio in Panel $\mathrm{A}$ is quite impressive.

\footnotetext{
${ }^{3}$ Earnings are before extraordinary items and special items, with an allocation of taxes to special items at the prevailing statutory tax rate for the year. The findings in Table 1 are similar when the return period begins four months after fiscal year and when we eliminate firms with stock prices less than $\$ 1.00$. For firms that are delisted during the 12-month holding period, we calculate the return for the remaining months by first applying the CRSP delisting return and then reinvesting any remaining proceeds at the risk-free rate. This mitigates concerns about potential survivorship bias. Firms that are delisted for poor performance (delisting codes 500 and 520-584) frequently have missing delisting returns. We apply delisting returns of $-100 \%$ in such cases, but the results are qualitatively similar when we make no such adjustment.

${ }^{4}$ There are a few loss firms also in E/P portfolio 2. Results are similar when we strictly confine all loss firms to portfolio 1, with portfolios 2-5 formed from ranking firms with positive $\mathrm{E} / \mathrm{P}$. The second sort on $\mathrm{B} / \mathrm{P}$ is not a further sort on E/P: calculations show that portfolio EP is held constant across levels of $\mathrm{B} / \mathrm{P}$, except for E/P portfolio 1 (loss firms) but where $\mathrm{E} / \mathrm{P}$ is actually negatively correlated with $\mathrm{B} / \mathrm{P}$.
} 
The results for value-weighted portfolio returns in Panel B are similar, though there is less of a return spread over the $\mathrm{E} / \mathrm{P}$ and $\mathrm{B} / \mathrm{P}$ spread. We report these returns understanding that investors often work with value-weighted portfolios to avoid weighting small firms too heavily. However, these returns somewhat dampen those from investing on the basis of $\mathrm{E} / \mathrm{P}$ and $\mathrm{B} / \mathrm{P}$ because, as in Fama and French (2012), we have implicitly confirmed that the book-to-price "value" effect is much reduced in large firms. Thus, weighting towards large market cap moves away from the effect under investigation. This highlights a point that we will return to later.

This strategy has presumably been trawled many times by value-growth investors, though not always with this structure. What explains the spread? The spread looks too large to be a free lunch; there is just too much money left on the table for a very simple strategy. This presumably cannot be explained by transaction costs. Does the return spread reflect differences for bearing risk, a trap to fall into?

\section{Connecting E/P and B/P to Growth and Risk: The Accounting}

Given price, $\mathrm{E} / \mathrm{P}$ and $\mathrm{B} / \mathrm{P}$ are accounting phenomena, that is, they depend of how earnings and book value are measured. Thus, if $\mathrm{E} / \mathrm{P}$ and $\mathrm{B} / \mathrm{P}$ indicate risk, it may have something to do with the accounting.

To illustrate, consider the B/P ratio for two investment funds, a ("risk-free") money market fund holding U.S. Government securities and a (risky) equity hedge fund. In both cases $\mathrm{B} / \mathrm{P}=1$, even though the two funds have different risk. This, of course, is because of mark-to-market accounting (strictly, fair value accounting) that yields an NAV on which investors can trade (in and out of the fund). B/P does not differentiate risk: fair value accounting takes away the ability 
to do so. However, for non-investment firms, so-called historical cost accounting is applied such that $\mathrm{B} / \mathrm{P} \neq 1$ (and usually is less than one). Does the accounting for $\mathrm{B} / \mathrm{P}$ indicate risk and expected return in this case?

A standard pricing formula sets up the answer to this question. For positive earnings,

$$
P_{0}=\frac{\text { Earning } S_{1}}{r-g}
$$

where $P_{0}$ is current price, Earnings $s_{1}$ is forward (year-ahead) earnings, $r$ is the required return for risk borne, and $g$ is the expected earnings growth after the forward year (both constants here just for simplicity). ${ }^{5}$ The forward $\mathrm{E} / \mathrm{P}$ ratio is thus

$$
\frac{\text { Earnings }_{1}}{P_{0}}=r-g
$$

This expression shows that the forward E/P ratio is increasing in the required return and decreasing in expected growth (as is well-recognized). Growth is typically seen as decreasing $\mathrm{E} / \mathrm{P}$ (and increasing $\mathrm{P} / \mathrm{E}$ ), and indeed equation (1a) shows that this is so for a given required return: higher expected growth means a higher price and a lower E/P. But what if buying that growth were risky? Then more growth would mean a higher required return, $r$. The effect of

\footnotetext{
${ }^{5}$ This formula is strictly correct only for full payout, for then the substitution of earnings for dividends maps directly to the no-arbitrage (constant discount rate) dividend discount model. The formula is often modified to accommodate different payout policies - with a constant payout ratio in the Gordon model, for example. But, for expositional purposes, simplicity is a virtue and, under Miller and Modigliani (1961) assumptions, payout is irrelevant: while less than full payout increases expected earnings growth, $g$, it does not affect price. By excluding growth that comes only from retention (dividend payout), we focus on growth that comes from the success of investments. Growth includes that from investing retained earnings in (growth-generating) investment, of course, and that is captured here. The point is that retention alone does not generate value-relevant growth, only growth from investment. Ohlson and Juettner-Nauroth (2005) develop a pricing model based on expected forward earnings and subsequent earnings growth that generalizes to all payout policies yet is dividend irrelevant.
} 
growth would go into $r$ rather than the price, yielding a higher $\mathrm{E} / \mathrm{P}$ to the extent that $r$ increases more than $g$. Indeed, if $r$ increased with $g$, one for one, then increased growth expectations would not affect the $\mathrm{E} / \mathrm{P}$ ratio.

Here is the point: in the determination of price in equation (1), earnings are capitalized at the rate, $r-g$. A given E/P indicates the difference between $r$ and $g$, so the investor observing an $\mathrm{E} / \mathrm{P}$ ratio is confronted with the question of whether the $\mathrm{E} / \mathrm{P}$ is due to risk or to expected growth. So, a given $\mathrm{E} / \mathrm{P}=r-g$ could indicate risk with no expected growth $(g=0)$, high growth with high risk (high $g$ and high $r$ ), or low growth with low risk (low $g$ and $r$ ). Clearly there is some sorting out to do. The value investor buying a high E/P stock could just be loading up on risk: that stock might not be a low growth stock at all, but rather a stock with high but risky growth. Such a stock is labeled a value stock that looks cheap, but may be a value trap.

It is not difficult to accept that buying earnings growth might be risky: a firm with high growth prospects ("growth options") is typically considered risky. However, accounting principles also come into play, and that introduces B/P. Dividing equation (1a) through by Earnings $/$ /Book Value,, $\mathrm{B} / \mathrm{P}$ is given by

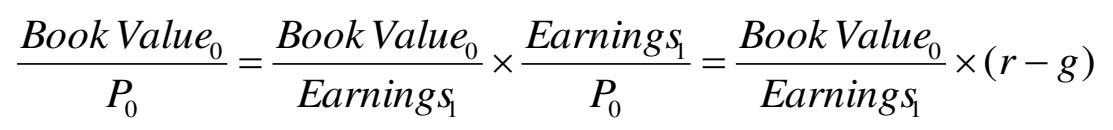

This equation expresses $\mathrm{B} / \mathrm{P}$ as the product of $\mathrm{E} / \mathrm{P}$ ratio and the (inverse of the) book return on equity, $R O E_{1}=\frac{\text { Earnings }_{1}}{B_{0}}$. It also establishes conditions under which $\mathrm{B} / \mathrm{P}$ indicates growth and the risk (and the required return) associated with growth, $r$ and $g$. For a given E/P and thus a given $r-g$, 
(i) $\quad \mathrm{B} / \mathrm{P}$ is determined by the (inverse of) $R O E$; a lower $R O E$ implies a higher $\mathrm{B} / \mathrm{P}$

(ii) $\mathrm{A}$ higher $\mathrm{B} / \mathrm{P}$ is associated with a higher $g$ if a lower $R O E$ is associated with a higher $g$ - that is, if a lower ROE implies higher future growth expectations.

(iii) If a higher $\mathrm{B} / \mathrm{P}$ is associated with a higher $g$, a higher $\mathrm{B} / \mathrm{P}$ is also associated with a higher $r$ (with $r-g$ unchanged for a given $\mathrm{E} / \mathrm{P}$ ).

In total, the three conditions state that, for a given $\mathrm{E} / \mathrm{P}, \mathrm{B} / \mathrm{P}$ is positively related to both expected earnings growth and the required return for risk, $r$ and $g$, if ROE is negatively associated with these features. Property (i) is just simple math, stating that, for a given $r-g, \mathrm{~B} / \mathrm{P}$ is determined by ROE. But properties (ii) and (iii) are conditional statements: if a lower $R O E_{1}$ implies higher future earnings growth, then $\mathrm{B} / \mathrm{P}$ is increasing in growth and the required return.

Table 1 ranks stocks on $\mathrm{B} / \mathrm{P}$ while holding $\mathrm{E} / \mathrm{P}$ constant. As $\mathrm{E} / \mathrm{P}=r-g$, the sort on $\mathrm{B} / \mathrm{P}$ down columns thus holds $r-g$ constant. So, these three points are relevant for the interpretation of the returns in that table. However, the conditional if in the statement (ii) that links $R O E$ to $g$ is critical. Is there a reason why expected growth and its risk might be inversely related to ROE? Later in the paper, we show that is the case empirically, but first we explain that it follows as a matter of accounting principle.

An Accounting Principle Connects ROE to Growth and Risk. Earnings add to book value, but under historical cost accounting earnings are not booked until prescribed conditions are satisfied; $P_{0}-B_{0}$ is simply future earnings that the market expects in setting the price, $P_{0}$, but which the accountants have yet to book to book value-the expected earnings are to be added to book value in the future. The median price-to-book in the U.S. since 1962 is about 1.6 (higher in 
more recent years), indicative of this delayed earnings recognition. The guiding accounting principle has to do with how accountants handle risk in booking earnings:

An Accounting Principle: Under uncertainty, the recognition of earnings is deferred to the future until the uncertainty has been resolved.

This "realization" principle, taught in basic Accounting 101 class, instructs the accountant to book earnings only when the risk of actually "earning" expected earnings is largely resolved. In terms of asset pricing theory, the accountant does not recognize earnings until the firm can book a low-beta asset, usually cash or a near-cash receivable. Delaying earnings recognition means more earnings in the future, that is, earnings growth. So, an expectation of future earnings that awaits "realization" is an expectation of earnings growth and, as that realization is tied to risk resolution, the expected growth is risky: it may not be realized. ${ }^{6}$ The principle potentially bears on $r$ and $g$ in equations (1) and (2).

The principle is an application of so-called conservative accounting, an apt term for dealing with risk. It has its expression in recognizing revenue only when a customer has been "sold," agreeing to a legally binding contract and, even then, only if "receipt of cash is reasonably certain." (Dear reader; we hope your Accounting 101 is coming back to you!) So, expected revenues from the prospect of future customers are not booked, even though the expectation is appropriately incorporated in the stock price. Accountants see value from prospective customers as risky—-the value may not be realized-and thus it is not unreasonable to conjecture that price, $P_{0}$, in equations (1) and (2) is also discounted for that risk. Even the

\footnotetext{
${ }^{6}$ Fairfield (1994) shows how the combination of E/P and B/P indicates future growth, but does not tie the growth to risk.
} 
receivables from actual sales are discounted (in allowances for credit losses) for the risk of not receiving cash from the sales.

Earnings is revenue minus expenses and this conservative accounting is reinforced by the accounting for expenses: investments that otherwise would be booked to the balance sheet are expensed in the income statement when the outcome from the investment is particularly uncertain. This reduces current earnings but increases expected future earnings, for now there is the prospect of future revenues from the investment but no amortization of the cost of the investment against those future revenues. And, on a lower current earnings base, there is higher expected growth. R\&D investment is the typical example: it may not produce saleable products (let alone customers), so it is particularly risky and expensed immediately. ${ }^{7}$ But the accounting treatment goes well beyond R\&D. The same expensing of investment against earnings applies to brand building (advertising to gain future revenue), organization and store opening costs, investment in employee training, software development, and investments in distribution and supply chains — often buried in the amorphous account, Selling, General, and Administrative expense (SG\&A). This accounting lowers current earnings but the investment produces future earnings growth if the earnings from the risky investments are realized. The if implies risk. ${ }^{8}$

This brings a different perspective to the $g$ in equation (1a). We often think of growth abstractly, with terms like "organic growth" and "economic growth." But expected growth is an

\footnotetext{
${ }^{7}$ The U.S. accounting standard that requires expensing of R\&D (FASB Statement No. 2) justifies the treatment because of "the uncertainty of future benefits." Under international financial reporting standards (IFRS), "research" is expensed but "development" is capitalized and amortized. The distinction is made (in IAS No. 38) under the criterion of "probable future economic benefits."

${ }^{8}$ The focus on conservative accounting is not to deny that earnings and book values might be manipulated, as entertained in a recent $F A J$ paper, Kok, Ribando and Sloan (2017). But the accounting principles invoked here are pervasive and dominating, subject to audit, with determining effects on earnings and book value.
} 
accounting phenomenon, induced by how one accounts for earnings and book value. With markto-market accounting there can be no expected growth: growth that might otherwise be expected is capitalized into the book value, as it is in price (and $\mathrm{B} / \mathrm{P}=1$ ). Growth only comes with delayed recognition of earnings, and accounting principles that induce this delay tie the growth to risk. If investors price the growth as risky, the growth affects $r$.

But how does $\mathrm{B} / \mathrm{P}$ come into play?

Conservative accounting reduces earnings in the E/P ratio but those earnings are also the numerator of $R O E$, so the accounting also reduces $R O E$, the relevant fundamental in equation (2). That ties $R O E$ to growth: the conditional if in property (ii) is satisfied by accounting principle. Thus, B/P is positively related to expected growth by the mathematical property (i). Further, by property (iii), $\mathrm{B} / \mathrm{P}$ also indicates the required return if the risk that growth may not be realized is priced. In buying a high $\mathrm{B} / \mathrm{P}$ "value" stock, an investor takes on this risk.

There is a flip side to conservative accounting that further connects $R O E$ to growth and risk: if the deferred earnings are recognized when risk is resolved, $R O E$ is higher. Earnings (in the numerator of ROE) are higher, not only because earnings have been realized, but because there is no deprecation or amortization charges against that revenue- the investments were written off. Further, the earlier expensing of the investments means that book values in the denominator of $R O E$ are lower - the assets generating the earnings are missing from the balance sheet. Thus, with higher realized earnings on a lower book value base, ROE is particularly high. 
A high $R O E$ thus indicates risk that has been resolved. ${ }^{9}$ And, for a given $\mathrm{E} / \mathrm{P}, \mathrm{B} / \mathrm{P}$ is correspondingly lower, by equation (2).

In sum, for a given $\mathrm{E} / \mathrm{P}$, a low $R O E$ due to conservative accounting implies higher growth and risk, and a high $R O E$ results from earnings (growth) being realized and a lowering of risk. And, by equation (2), $\mathrm{B} / \mathrm{P}$ distinguishes whether a given $\mathrm{E} / \mathrm{P}=r-g$ is one with high $r$ and high $g$ or with low $r$ and low $g$. Properties (ii) and (iii) stand as a matter of accounting principle.

Some case studies further illustrate the point (Editor: place in sidebar?):

A high E/P is often seen as a value stock. In early 2018, Verizon Communications, Inc. traded at a forward $\mathrm{E} / \mathrm{P}$ of 9.6 percent, putting it into the high $\mathrm{E} / \mathrm{P}$ portfolio 5 in the Table 1 matrix. Its B/P was 0.22 , placing it in cell $(\mathrm{E} / \mathrm{P}=5, \mathrm{~B} / \mathrm{P}=1)$ in the matrix. That implies a forward $\mathrm{ROE}=9.6 \times$ $4.45=42.7$ percent (and the trailing ROE was 88.9 percent). The stock looks relatively low risk-it is realizing earnings on book value. In contrast, Sanofi, the pharmaceutical company, traded at a forward $\mathrm{E} / \mathrm{P}$ of 8.7 percent, also in $\mathrm{E} / \mathrm{P}$ portfolio 5, but with a $\mathrm{B} / \mathrm{P}$ of 0.71 and a corresponding forward ROE of 12.5 percent (with a trailing ROE of 6.8 percent). It is in cell (E/P $=5, \mathrm{~B} / \mathrm{P}=4)$. Sanofi's income statement reports $\mathrm{R} \& \mathrm{D}$ expenditure of 15.1 percent of revenue, with selling and promotion of drugs at 27.8 percent of revenue. These expenditures to earn future revenue (growth) depress the ROE. As those revenues are uncertain, the firm looks riskier than Verizon.

After IPO, Facebook, Inc. traded in 2013 with significant growth prospects built into its $\mathrm{P} / \mathrm{E}$ of 83 (in E/P portfolio 2). However, the firm was reporting an ROE of only 2.2 percent, looking unprofitable, placing it in a low $\mathrm{ROE}$ cell $(\mathrm{E} / \mathrm{P}=2, \mathrm{~B} / \mathrm{P}=4)$. The low $\mathrm{ROE}$ was due to the expensing of development and advertising costs amounting to 45.1 percent of sales. While these investments projected higher future earnings, the earnings were uncertain - they might not be realized, and the low ROE conveyed the uncertainty. Should those earnings be realized, Facebook would have significant earnings growth, not only from the revenues but because only variable costs would have to be covered: fixed costs of investments have already been expensed. And, with these investments omitted from the balance sheet, it would also have a very high ROE on a low asset base if the earnings growth were realized. By 2017, Facebook had considerable

\footnotetext{
${ }^{9}$ The effect of conservative accounting on $R O E$ is simply by the constriction of the accounting - the accounting principles invoked along with the debit and credits of the double-entry system. Feltham and Ohlson (1995) and Zhang (2000) demonstrate. Penman and Zhang (2018) develop a measure of the effect of conservative accounting on $R O E$ and document empirically how this measure affects $R O E$ in the way described.
} 
success in generating those earnings, now reporting an ROE of 23.8 percent. That is a migration to cell $(\mathrm{E} / \mathrm{P}=2, \mathrm{~B} / \mathrm{P}=1)$, and it is considerably less risky: the reported beta is now 0.7 .

Twitter, Inc. went to IPO in November 2013, closing on its first trading day priced at 26 times estimated 2014 sales, a price embedding significant growth expectations. The firm was reporting losses (and a negative ROE). The low ROE was due largely to the expensing of R\&D, promotion, and software development that amounted to 80 percent of revenue, placing it in E/P portfolio 1 with a low ROE. These expenditures were made to generate revenue and earnings growth, but there was uncertainty about whether the expected revenues and earnings would be realized. In 2017, Twitter continued to report losses (and an ROE of -2.2 percent), largely attributable to the expensing of investments with uncertain payoffs, still 51.5 percent of revenue. And, relative to Facebook, those uncertainties persist. (As a postscript, Twitter reported positive quarterly earnings for the first time in 2018, with a large jump in its share price: uncertainty (somewhat) resolved.)

Coca Cola Company traded at a P/E of 19.7 in early 2018. It was reporting an ROE of 26 percent for 2017 due largely to a brand investment that is omitted from the balance sheet, but one that actually delivers sales and earnings in the numerator of the ROE. It is in cell $(\mathrm{E} / \mathrm{P}=3, \mathrm{~B} / \mathrm{P}=1)$. This is a low-risk ROE, for the risk taken with the brand building investment has been resolved or "realized." Coke has a beta of 0.6.

Amazon.com, Inc. reported a loss for the third quarter of 2013, as it had done for the full year, 2012. The losses, on rising sales, continued into 2014, and were attributed to "spending on technology and content, such as video streaming and grocery delivery to mobile devices" and the firm's "willingness to win customers by losing money." These investments were being expensed directly to the income statement, yielding a negative ROE. While high expectations were built into the share price, the results of these investments were uncertain; the added customers had yet to be realized. Revenues are now rising significantly, but further investment in software, drone technology, and retail distribution are still reducing earnings. With a forward P/E of 192 (and an $\mathrm{E} / \mathrm{P}$ of 0.5 percent) in 2017 , it is in the $\mathrm{E} / \mathrm{P}=2$ cell: the market is pricing in a lot of earnings growth. But, with a $\mathrm{P} / \mathrm{B}$ of $22, \mathrm{ROE}=\mathrm{E} / \mathrm{P} \times \mathrm{P} / \mathrm{B}=0.5 \% \times 22=11 \%$. This is not a particularly strong rate of return; indeed, many value investors have shunned Amazon (or shorted it) because “it is not very profitable." But the ROE is still being depressed by risky investments. Amazon is not a firm that is unprofitable, but rather one that is potentially very profitable if investments pay off: there is risk to achieving this growth. The standard view of Amazon-a firm investing heavily with the hope of becoming hugely profitable - is reflected in the accounting. (See also press reports in The Wall Street Journal, October 25, 2013, p. B3 and Financial Times of the same date, p. 13. The Wall Street Journal also reported (p. C1) a study by Morgan Stanley that 89 percent of a present value calculation on Amazon related to cash flows forecasted for years after 2020.)

During the 1990s, Starbucks Corporation was trading with considerable growth expectations built into its market price; the P/E was 51 in 1999. However, it was reporting a book rate of return on its operations of about 10 percent on average, in cell $(\mathrm{E} / \mathrm{P}=2, \mathrm{~B} / \mathrm{P}=3)$. Starbucks was expanding stores aggressively, expensing store-opening expenses, advertising, employee training, and its development of coffee supply chains. This expensing depressed the book return, 
an indication that the growth strategy was risky. As it happened, the strategy paid off, with the book rate of return rising to over 20 percent by 2005. But the risky strategy could have gone the other way. By 2017, ROE was 52 percent with a P/E of 27 (an E/P of 3.7 percent) and a P/B of $14: \mathrm{ROE}=3.7 \% \times 14=51.8 \%($ cell $\mathrm{E} / \mathrm{P}=3, \mathrm{~B} / \mathrm{P}=1)$. While the $\mathrm{P} / \mathrm{E}$ still indicates significant expected earnings growth, the corresponding ROE indicates there is relatively low risk to the growth: the beta is 0.5. (Penman, 2012, Chapter 5 lays out the Starbucks case in more detail.)

\section{Connecting E/P and B/P to Growth and Risk: The Data}

Properties (i) - (iii) are conditions under which B/P indicates growth and risk. Property (i) does not have to be tested; it is straight math, so will always hold empirically. However, while accounting principles suggest that the conditional properties (ii) and (iii) will be satisfied, the proof in in the pudding. Here we subject them to empirical testing.

For a Given E/P, B/P is Positively Related to Subsequent Earnings Growth. The portfolios in Table 2 are the same portfolios as in Table 1, that is, with B/P portfolios formed within a given E/P portfolio. ${ }^{10}$ However, Table 2 now reports mean earnings growth rates two years ahead for these portfolios. ${ }^{11}$ As the ranking on $\mathrm{B} / \mathrm{P}$ to form the $\mathrm{B} / \mathrm{P}$ portfolios is an inverse ranking on

\footnotetext{
${ }^{10}$ Although earnings are purged on obvious transitory items (footnote 3), there may be concerns that one year's trailing earnings may still contain transient components, and thus not a good indicator of forward earnings in equation (1). So, the analysis in Tables $1-3$ was repeated with E/P as the sum of the past three years of earnings-toprice (with dividends reinvested), with similar results.

${ }^{11}$ Earnings growth two years ahead is hardly sufficient to capture the complete stream of future earnings in the growth rate in equation (1), though growth for that year likely is a forecast of subsequent growth: results for growth three, four and five years-ahead are similar. However, survivorship frustrates the observation of long-run ex post growth as an indication of ex ante growth. That, of course, raises the question of whether the results are affected by such bias, for firms do disappear within two years. The returns in Table 1 include delisting returns, but there is no accommodation for the growth findings here. So, we ascertained the fraction of firms that ceased to exist in the second year for performance-related reasons indicated by CRSP delisting codes. The delisting rate was higher for high $\mathrm{B} / \mathrm{P}$ firms, an average of 8.9 percent over all high $\mathrm{B} / \mathrm{P}$ portfolios in the first year ahead versus 7.7 percent for low $\mathrm{B} / \mathrm{P}$ portfolios. The corresponding delisting rates over the next two years were 20.8 percent versus and 16.9 percent. This reinforces our inferences rather than qualifying them; pertinent to the risk discussion that follows, delisted firms are those that either had low payoffs with firm failure or high payoffs in being acquired, that is, they exhibit a wider spread of outcomes.
} 
ROE, the high (low) B/P portfolios are low (high) ROE portfolios. ${ }^{12}$ Thus the analysis tests the conditional if in property (ii): Is ROE negatively correlated with future growth for a given E/P? And, to the issue at hand: Is $\mathrm{B} / \mathrm{P}$ positively correlated with future growth for a given E/P?

Table 2 supplies the answer: Yes. E/P predicts subsequent earnings growth (across rows in the table), as one expects of a $\mathrm{P} / \mathrm{E}$ ratio. But, for a given $\mathrm{E} / \mathrm{P}, \mathrm{B} / \mathrm{P}$ is positively correlated with growth (down columns), with the difference in growth rates particularly strong for lower E/P portfolios with the higher growth expectations. As $\mathrm{B} / \mathrm{P}$ is inversely related to ROE, the conditional if in property (ii) is satisfied empirically, in line with the accounting. ${ }^{13}$ Thus, the return spread for the same portfolios in Table 1 is explained by buying future earnings growthand with buying earnings and book values governed by accounting principles that indicate the growth.

But is the expected earnings growth associated with high $\mathrm{B} / \mathrm{P}$ growth that is at risk? Only then could the returns in Table 1 be attributed to reward for risk bearing.

\footnotetext{
${ }^{12}$ So, mean ROE for the low $\mathrm{B} / \mathrm{P}$ portfolio in $\mathrm{E} / \mathrm{P}$ portfolio 3 is 24.1 percent, compared with 4.8 percent for the high $\mathrm{B} / \mathrm{P}$ portfolio, and similarly so for other $\mathrm{E} / \mathrm{P}$ portfolios. The exception is portfolio 1 with negative earnings where the low $\mathrm{B} / \mathrm{P}$ portfolio has a lower negative ROE than the (negative) ROE for high $\mathrm{B} / \mathrm{P}$, as also implied by equation (2) when earnings are negative.

${ }^{13}$ Because added investment from retention in the first year ahead adds to earnings growth two years ahead, we also calculated the residual earnings growth rate two years ahead to subtract for the added investment. Residual earnings was calculated as earnings with a charge against beginning-of-period book value at the prevailing yield on the tenyear U.S government note. Results were similar. Portfolios are formed on the basis of reported E/P (before extraordinary and special items), not the forward E/P in equation (1a). This is because we wish to discern the information conveyed by the accounting, not forward estimates, and the trailing $\mathrm{E} / \mathrm{P}$ (purged of the transitory items) is a good indicator of forward E/P. The mean rank correlation between trailing earnings-to-price (as we have measure it) and realized forward earnings-to-price is 0.63 . Of course, equation (1) can also be expressed in terms of trailing earnings, with earnings growth, $g$, forecasted from the current year onwards rather than after the forward year. This recasts the analysis as investing on the basis of trailing $\mathrm{E} / \mathrm{P}$ and $\mathrm{B} / \mathrm{P}$, with no loss of insight.
} 


\section{For a Given E/P, B/P is Positively Associated with Subsequent Earnings Growth at Risk.}

Property (iii) connects $\mathrm{B} / \mathrm{P}$ to both growth and risk. Tables 3 and 4 report that the portfolios in Table 1 and 2 are not only associated with expected growth, but also to the risk that the growth may not be realized. They validate that accounting principles not only connect $R O E$ to growth, but buying that growth also comes with risk.

Table 3 shows that the E/P-B/P sort of Tables 1 and 2 is also a sort on the variation in earnings outcomes. For each portfolio, Panels A and B report the standard deviation and interdecile range (IDR) of realized earnings one year ahead (relative to price). Panels C and D report the same statistics for realized earnings growth rates two years ahead. The IDR, the $90^{\text {th }}$ percentile minus the $10^{\text {th }}$ percentile of realizations, focuses on extreme (tail) realizations, a risk the investor is particularly concerned about. Both the standard deviation and IDR are calculated from the time series of earnings outcomes for portfolios over the sample period.

There is some variation in the volatility of earnings outcomes across E/P portfolios (across the top row in the panels), due mainly to significantly high volatility in the negative E/P portfolio, portfolio 1 . However, to the issue at hand, both the standard deviation and IDR increase over $\mathrm{B} / \mathrm{P}$ for a given $\mathrm{E} / \mathrm{P}$ (down columns): $\mathrm{A}$ higher $\mathrm{B} / \mathrm{P}$ indicates that one is buying riskier forward earnings and subsequent earnings growth, more so for the earnings growth rates. This is so for all levels of E/P, including high E/P ("value") and low E/P ("growth"). It also is so for negative $\mathrm{E} / \mathrm{P}$ (loss firms) that are often associated with particularly strong expensing of investment.

To connect the variance of growth rates to that of stock returns, we calculated the correlation between the standard deviation of earnings growth rates for the $\mathrm{B} / \mathrm{P}$ portfolios (down 
columns in Panel C) with the standard deviation of returns in the same year as the growth realizations. These correlations are reported at the bottom of Panel C: the variance of realized returns is associated with the variance of realized growth rates. The correlation across the whole spread on $\mathrm{E} / \mathrm{P}, \mathrm{B} / \mathrm{P}$ portfolios is $0.69 .^{14}$

In short, not only does B/P indicate expected growth (in Table 2) but also the variance around that expectation. In terms of equation (1a), B/P indicates whether a given E/P is one with high growth and risk or low growth and risk. The finding for the interdecile range is pertinent, for therein is the trap about which the investor is particularly concerned: B/P indicates a higher chance of a high-growth outcome but also a higher chance of growth falling in the lower tail. The reward to that risk shows up in the return spread in Table 1.

Under asset pricing theory, risk is priced only if it pertains to sensitivity to risk that cannot be diversified away. So, risk to earnings is associated with shocks to market-wide earnings. Accordingly, Table 4 reports earnings betas from estimating the following regression for each portfolio:

$$
\text { Portfolio } \frac{\text { Earning } s_{1}}{P_{0}}(t)=\alpha+\beta \text {. Market }- \text { wide } \frac{\text { Earning } s_{1}}{P_{0}}(t)+\varepsilon_{t}
$$

The regression is estimated in time series over all years, $t$, in the sample period. The earnings realizations are for the forward year, that is, the same year during which portfolio returns are

\footnotetext{
14 The connection of return realizations to earnings realizations accords with the observation in La Porta, Lakonishok, Shleifer, and Vishny (1997) that the value-growth spread over the three days surrounding quarterly earnings announcements accounts for about 30 percent of the annual return spread.
} 
observed in Table 1, so the betas are those experienced during the holding period, not historical betas. To align realizations in calendar time, the regression is estimated for firms with December 31 fiscal-years only. The portfolio earnings yield is the mean for the portfolio, and the marketwide earnings yield is the aggregate earnings for all firms in the sample in that year relative to aggregate price at the beginning of the period. ${ }^{15}$

The betas in Panel A of Table 4 are increasing in $\mathrm{B} / \mathrm{P}$ for a given E/P portfolio. The average R-square for the regressions is $60.7 \%$ : Market-wide earnings explain a significant part of portfolio earnings. Separating years in which the market-wide earnings yield was up from the previous year (up-markets) from years when it was down (down-markets), the conditional betas in Panels B and C indicate that higher B/P have higher up-market betas, delivering higher earnings in good times, but also have higher down-market betas, a trap that is compensated with higher upside potential. Correspondingly, low B/P portfolios have considerably lower betas in down-markets, but their upside beta is also lower. In sum, the variation in earnings outcomes across B/P portfolios in Tables 3 is due, in part, to economy-wide shocks. ${ }^{16}$

If the market prices the fundamental risk documented in these tables, the spread of average portfolio returns in Table 1 can be the interpreted as reward for bearing that risk. Of course, the returns in Table 1 represent reward for risk only if the market prices risk efficiently. They could be abnormal (alpha) returns because the market does not price the earnings growth appropriately. We take no stand on this-we (collectively) do not have a generally accepted asset

\footnotetext{
${ }^{15}$ For the portfolios, means are arithmetic means. Similar results were obtained with weighted means, that is, with portfolio earnings calculated as the total earnings for the portfolio relative to price. The market earnings are total earnings for all firms relative to price.

16 The earnings betas here are consistent with Cohen, Polk, and Vuolteenaho (2009) and Campbell, Polk, and Vuolteenaho (2010) who attribute the higher returns to value stocks to higher "cash flow betas," that is, the sensitivity to news about future cash flows.
} 
pricing model that delivers an expected return benchmark. But, for those inclined to see the returns as alpha, the analysis brings caveat emptor: in trolling for alpha, you are taking on riskyou may be falling into a value trap.

One might suggest that the return spreads in Table 1 are just too large to be explained by risk. But the period covered, 1963-2015, was one of significant corporate earnings growth and a bull market in stocks. Buying growth is risky, but in this happy period, the bet paid off handsomely —it was, after all, "The American Century." Koijen, Lustig, and Van Nieuwerburg (2017) show that "value" pays off when economic activity increases and that appears to be the case here. Results are similar over 10-year subperiods during 1963-2015.

However, the trap is there, as the correlations between the variation in realized growth rates and variation in returns in Panel C of Table 3 indicate. Growth expectations have been shocked in recent years, with consequent shocks to stock prices. So, Table 5 reports portfolio returns during the two years, 2008 and 2015, when total returns for the S\&P 500 were lowest in the last 10 years of the sample period (-37.0\% in 2008 and 1.38\% in 2015). Returns are from April of the year through March of the following year for December 31 fiscal-year firms, the 12 months after earnings and book values are available with a three-month reporting lag. In the 2015 period, the spread of returns over $\mathrm{B} / \mathrm{P}$ portfolios was positive for the low $\mathrm{E} / \mathrm{P}$ portfolios (albeit considerably lower than in Table 1), but negative for E/P portfolios 3-5. In the financial crisis year, 2008, when growth expectations took a large hit, the spreads were negative for all $\mathrm{E} / \mathrm{P}$ portfolios: for a given $\mathrm{E} / \mathrm{P}$, high $\mathrm{B} / \mathrm{P}$ (and low $R O E$ ) earned lower returns than low $\mathrm{B} / \mathrm{P}$ (high ROE). 


\section{Firm Size and Value vs. Growth Investing}

In Table 1, the return spreads for value-weighted returns are lower than those for equallyweighted returns, suggesting that the phenomena that we have documented are stronger in small firms than large firms. That makes sense. Small firms are more likely to be growth prospects, but with growth that is at risk: consider the biotech start-up investing in $R \& D$ with little revenue yet versus the mature pharmaceutical with a product line realizing earnings from past R\&D. Several papers, including Loughran (1997), Asness, Frazzini, Israel, and Moskowitz (2015) and Kok, Ribando, and Sloan (2017), have documented that the book-to-price premium is absent from large-cap stocks. Is that because large firms are those with lower growth prospects or expected growth with less risk?

Figure 1 suggest so. It depicts the difference between high and low B/P portfolio returns within the five E/P groups in Table 1, but now differentiated by size. Small firms are the smallest $30 \%$ by market cap, large firms the highest $30 \%$, and medium firms the rest. There are some differences in return spreads across $\mathrm{E} / \mathrm{P}$ portfolios but, for a given $\mathrm{E} / \mathrm{P}$, the return spread between high and low $\mathrm{B} / \mathrm{P}$ portfolios is decreasing in firm size. The $\mathrm{B} / \mathrm{P}$ return spread is negligible for large firms in all E/P portfolios (and similar to that for small firms in the high $\mathrm{E} / \mathrm{P}$ portfolio). The same pattern is observed in 10-year subperiods between 1963 and 2015.

Table 6 draws further insights for size quintiles. ${ }^{17}$ In the (E/P, B/P) pairs reported for the quintiles, $\mathrm{E} / \mathrm{P}$ is increasing in firm size in the table, but $\mathrm{B} / \mathrm{P}$ is decreasing. The return spread for High - Low E/P portfolios do not vary much over portfolios, except for the largest quintile.

\footnotetext{
${ }^{17}$ A similar table (with decile portfolios) is in Penman, Reggiani, Richardson, and Tuna (2018).
} 
However, for High - Low B/P portfolios within E/P portfolios, the return spread is decreasing in firm size, as in Figure 1, and quite small for the larger firms in the top two quintiles. The table then reports estimated weights on $\mathrm{E} / \mathrm{P}$ and $\mathrm{B} / \mathrm{P}$ to indicate their relative importance in projecting forward returns, such that $R_{t+1}=w_{1} \frac{E_{t}}{P_{t}}+w_{2} \frac{B_{t}}{P_{t}}$. Weights are fitted using the Theil-Sen robust estimator; that is, the weights are the median values of $w_{1}$ and $w_{2}$ from fitting for all possible combinations of observations within the portfolio for each year, with the reported weights being the mean over years.

The mean weights on E/P increase with firm size. They are approximately equal to 1.0 for the largest firms, with the weight on B/P then close to zero; for large firms, $R_{t+1}=1.0 \frac{E_{t}}{P_{t}}+0.0 \frac{B_{t}}{P_{t}}$. In short, for large firms, the expected return in equation (1a) is approximated by $\frac{\text { Earning }_{1}}{P_{0}}=r$, on average. That accords with the observations in other papers that the book-to-price premium is absent in large-cap stocks. However, we provide an explanation: B/P plays no role (incremental to $\mathrm{E} / \mathrm{P}$ ) when there is little expected growth at risk.

As the table moves through medium-cap to small-cap (from right to left in the table), the weight shifts from E/P to B/P. Smaller firms are likely to have higher risky growth, and that must be weighed in. Indeed, the Table also reports that the mean realized earnings growth two-years ahead $(t+2)$ is decreasing in firm size, as are the other metrics reported in Table 3 that indicate risk around mean growth, the standard deviation and IDR of earning growth rates: smaller firms not only have higher expected growth but growth more likely to deviate from expectation considerably. Table 6 adds another measure, the earnings grow beta, which measures the 
sensitivity of earning growth to variation of market-wide growth rates. These betas, too, are decreasing in firm size. The mean and median $R O E$ in the table are increasing in size and are also negatively correlated with growth and the variability of growth realizations - as expected under the accounting principles.

These findings raise the specter than the so-called size effect in returns is really a discount to price for expected growth that may not be realized, not a separate "factor" from B/P.

\section{(Mis)Labelling Value and Growth}

Our analysis challenges the standard labels, "value" versus "growth" for low pricing multiples versus high multiples. Truth in advertising would demand that "growth" means higher expected earnings growth. That is so with the E/P ratio, as Table 2 confirms, but not necessarily so for a $\mathrm{B} / \mathrm{P}$ ratio.

A low B/P is commonly considered to be "growth." Indeed, equation (2) indicates that, for a given $R O E_{1}$ and required return, $\mathrm{B} / \mathrm{P}$ is decreasing in expected growth. However, $R O E$ also enters the equation. If a low $R O E$ is associated with higher expected growth, then $\mathrm{B} / \mathrm{P}$ in equation (2) is positively associated with growth. ${ }^{18}$

The confusion in labeling increases when it is said that "growth" yields lower returns, a common attribution. That seems odd, on the face of it, as one typically sees growth as risky, requiring a higher return. An understanding of the accounting further points to growth as risky;

\footnotetext{
${ }^{18}$ In Table 2, B/P is positively correlated with subsequent earnings growth conditional on E/P. However, Penman, Reggiani, Richardson, and Tuna (2018) report that B/P is unconditionally positively correlated with subsequent earnings growth. Chen (2017) reports that low B/P stocks do not have significantly higher dividend growth than high $\mathrm{B} / \mathrm{P}$.
} 
the mantra of the fundamentalist — beware of buying growth, for growth is risky — takes on added meaning when one appreciates the accounting for earnings and book value. Labeling presumably is supposed to convey meaning. The labels, "value" and "growth" confound.

The "value" label is sometimes applied to just B/P, with the interpretation that price (in the denominator) discounts for risk, yielding a higher B/P when expected payoffs are risky. We consider $\mathrm{B} / \mathrm{P}$ along with $\mathrm{E} / \mathrm{P}$ to introduce both earnings and book value and thus ROE that then conveys the risk that discounts the price. Earnings and book value "articulate" in the doubleentry system - the accounting for book value also affects earnings — so one cannot consider the $\mathrm{B} / \mathrm{P}$ without the $\mathrm{E} / \mathrm{P}$. Stated differently, if one is to understand $\mathrm{B} / \mathrm{P}$, one must understand the earnings associated with the book value (ROE). The double-entry accounting system of Luca Pacioli in 1494 that proved so useful to the Venetian merchants and many merchants since is also useful for conveying the risk of investing in those merchants.

With respect to the unconditional correlation of $\mathrm{B} / \mathrm{P}$ with stock returns, note that the cross-sectional correlation between $\mathrm{B} / \mathrm{P}$ and $\mathrm{E} / \mathrm{P}$ is 0.25 , on average, and $\mathrm{E} / \mathrm{P}$ predicts returns in Table 1 (and strongly so for large firms in Table 6). Further, conditional on E/P, B/P further predicts returns, contributing to the unconditional correlation of $\mathrm{B} / \mathrm{P}$ with returns. This is not to dismiss other possible explanations for the $\mathrm{B} / \mathrm{P}$ effect, but to point out that part of the explanation centers on the accounting and what it reveals about risk.

\section{Conclusion}

This paper explains the value trap in terms of accounting fundamentals. In buying "value" firms with low multiples, the investor may be taking on risk of buying earnings growth that may not 
materialize. A relatively high E/P stock, a so-called "value" stock, is typically viewed as one with low growth expectations but in fact could be one with high growth expectations but growth that is risky. By adding $\mathrm{B} / \mathrm{P}$, the investor understands that risk, for earnings together with book value yield the book rate of return, ROE that indicates not only expected growth, but also the risk in buying that growth. This is due to accounting principles for measuring earnings and book value that evaluate risk. The paper lays out this accounting and brings it to bear on assessing the risk in buying $\mathrm{E} / \mathrm{P}$ and $\mathrm{B} / \mathrm{P}$ - the risk of falling into the value trap.

Value investors screen on high $\mathrm{E} / \mathrm{P}$ and $\mathrm{B} / \mathrm{P}$ with the idea that low prices relative to earnings and book value indicate cheap stocks. There may be alpha in this strategy, but the analysis here provides a warning: buying "value" may be buying risky earnings growth. 


\section{References}

Asness, Clifford. 2003. "Fight the Fed Model: the Relationship between Future Returns and Stock and Bond Market Yields.” Journal of Portfolio Management, vol. 30, no. 1: 11-24.

Asness, Clifford, Andrea Frazzini, Ronen Israel, and Tobias Moskowitz. 2015. "Fact, Fiction, and Value Investing." Journal of Portfolio Management, vol. 42, no. 1: 34-52.

Basu, Sanjoy. 1977. "Investment Performance of Common Stocks in Relation to their PriceEarnings Ratios: A test of the Efficient Market Hypothesis." The Journal of Finance vol. 32, no. 3 (June): 663-682.

Basu. 1983, Sanjoy. "The Relationship between Earnings Yield, Market Value, and Return for NYSE Stocks: Further Evidence.” Journal of Financial Economics, vol. 12, no. 1 (June): 129-56.

Campbell, John, Christopher Polk, and Tuomo Vuolteenaho. 2010. "Growth or Glamour? Fundamentals and Systematic Fisk in Stock Returns." Review of Financial Studies, vol. 23, no. 1 (January): 305-344.

Chen, Huafeng. 2017. "Do Cash Flows of Growth Stocks Really Grow Faster?” Journal of Finance, vol. 72, no. 5 (October): 2279-2330.

Cohen, Randolph, Christopher Polk, and Tuomo Vuolteenaho. 2009. “The Price is (Almost) Right." Journal of Finance, vol. 64, no. 6 (December): 2739-2782.

Doukas, John, Chansog kim, and Christos Pantzalis. 2002. "A Test of the Errors-in-Expectations Explanation of the Value/Glamour Stock Returns Performance: Evidence from Analysts' Forecasts." Journal of Finance, vol. 57, no. 5 (October): 2143-2165.

Doukas, John, Chansog Kim, and Christos Pantzalis. 2004. "Divergent Opinions and the Performance of Value Stocks.” Financial Analysts Journal, vol. 60, no. 6 (November/December): 55-64.

Estrada, Javier. 2009. "The Fed Model: The Bad, the Worse, and the Ugly." Quarterly Review of Economics and Finance, vol. 49, no. 2 (May): 1-25.

Fairfield, Patricia. 1994. "P/E, P/B, and the Present Value of Future Dividends." Financial Analysts Journal, vol. 50, no. 4 (July/August): 23-31.

Fama, Eugene, and Kenneth French. 1995. "Size and Book-to-Market Factors in Earnings and Returns." Journal of Finance, vol. 50, no. 1 (March): 131-155.

Fama, Eugene, and Kenneth French. 2012. "Size, Value, and Momentum in International Stock Returns." Journal of Financial Economics, vol. 105, no. 3 (September): 457-472. 
Feltham, Gerald, and James Ohlson. 1995. "Valuation and Clean Surplus Accounting for Operating and Financial Activities." Contemporary Accounting Research, vol. 11, no. 2 (Spring): 689-731.

Jaffe, Jeffrey, Donald Keim, and Randolph Westerfield. 1989. "Earnings Yields, Market Values, and Stock Returns.” Journal of Finance, vol. 44, no. 1 (March): 135-148.

Koijen, Ralph, Hanno Lustig, and Stijn Van Nieuwerburg. 2017. "The Cross-Section and TimeSeries of Stock Returns.” Journal of Monetary Economics, vol. 88, (June): 50-69.

Kok, U-Wen, Jason Ribando, and Richard Sloan. 2017. "Facts about Formulaic Value Investing." Financial Analysts Journal, vol. 73, no. 2: 81-99.

La Porta, Rafael, Josef Lakonishok, Andrei Shleifer, and Roert Vishny. 1997. "Good News for Value Stocks: Further Evidence on Market Efficiency.” Journal of Finance, vol. 52, no. 2 (June): 859-874.

Lander, Joel, Athanasios Orphanides, and Martha Douvogiannis. 1997. "Earnings Forecasts and the Predictability of Stock Returns: Evidence from Trading the S\&P." Journal of Portfolio Management, vol. 23, no. 4 (Summer): 24-35.

Loughran, Tim. 1997. "Book-to-Market across Firm Size, Exchange, and Seasonality: Is there an Effect?” Journal of Financial and Quantitative Analysis, vol. 32, no. 3 (September): 249-268.

Miller, Merton, and Franco Modigilani. 1961. "Dividend policy, growth and the valuation of shares." Journal of Business, vol. 34, no. 4 (October): 411-433.

Ohlson, James 2008. "Risk, growth, and permanent earnings." Unpublished paper, New York University Stern School of Business.

Ohlson, James, and Brate Juettner-Nauroth. 2005. "Expected EPS and EPS Growth as Determinants of Value." Review of Accounting Studies, vol. 10, no. 2-3: 349-365.

Penman, Stephen. 2012. “Accounting for Value” (New York: Columbia University Press).

Penman, Stephen, and Francesco Reggiani. 2013. "Returns to Buying Earnings and Book Value: Accounting for Growth and Risk. Review of Accounting Studies, vol. 18, no. 4 (December): 1021-1049.

Penman, Stephen, Francesco Reggiani, Scott Richardson, and İrem Tuna. 2018. "A Framework for Identifying Accounting Characteristics for Asset Pricing Models, with an Evaluation of Book-to-Price." European Financial Management, forthcoming.

Penman, Stephen, and Xiao-Jun Zhang. 2018. "Connecting Book Rate of Return to Risk: The information Conveyed by Conservative Accounting." Unpublished paper, Columbia University and University of California, Berkeley. At http://ssrn.com/abstract=2402933. 
Piotroski, Joseph, and Eric So. 2012. "Identifying Expectation Errors in Value/Glamour Strategies: A Fundamental Analysis Approach." Review of Financial Studies, vol. 25, no. 9 (September): 2841-2875.

Salomons, Roelof. 2006. "A Tactical Implication of Predictability: Fighting the Fed Model." Journal of Investing, vol. 15, no. 2 (Summer): 87-98.

Zhang, Xiao-Jun. 2000. "Conservative Accounting and Equity Valuation.” Journal of Accounting and Economics, vol. 29, no. 1 (February): 125-149. 


\section{Figure 1. Mean Equally-Weighted Returns Between High and Low B/P Portfolios within Five E/P Portfolios, by Firm Size.}

The figure reports Table 1 returns by firm size. Within each E/P portfolio in that Table, the HighLow return spread on B/P is depicted for three size portfolios. Small firms are the lowest 30 percent by market capitalization and large firms the highest 30 percent.

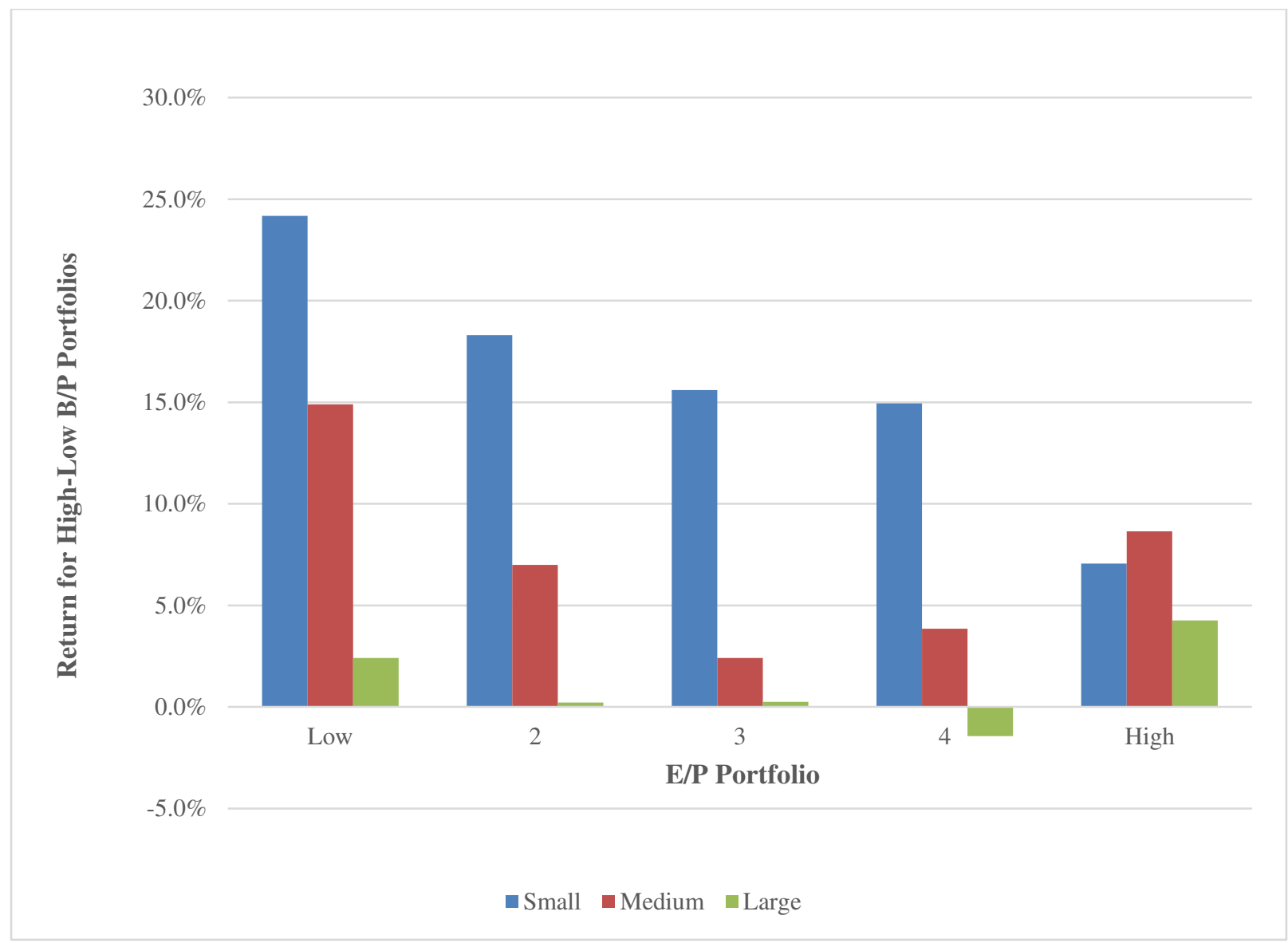


Table 1. Mean Annual Returns for Portfolios Formed by Ranking Firms Each Year on E/P and B/P; 1963-2015

The table present average returns over years for portfolios formed by ranking firms each year on $\mathrm{E} / \mathrm{P}$ and then, within each E/P portfolio, by ranking on B/P. Panel A reports equally-weighted portfolio returns and Panel B value-weighted returns. $t$-statistics are tests for significant differences between the means for High and Low portfolios and are calculated as the mean difference over years relative to its standard error calculated from the time series of return differences.

A. Mean Returns (in Percent) for Equally-weighted Portfolios

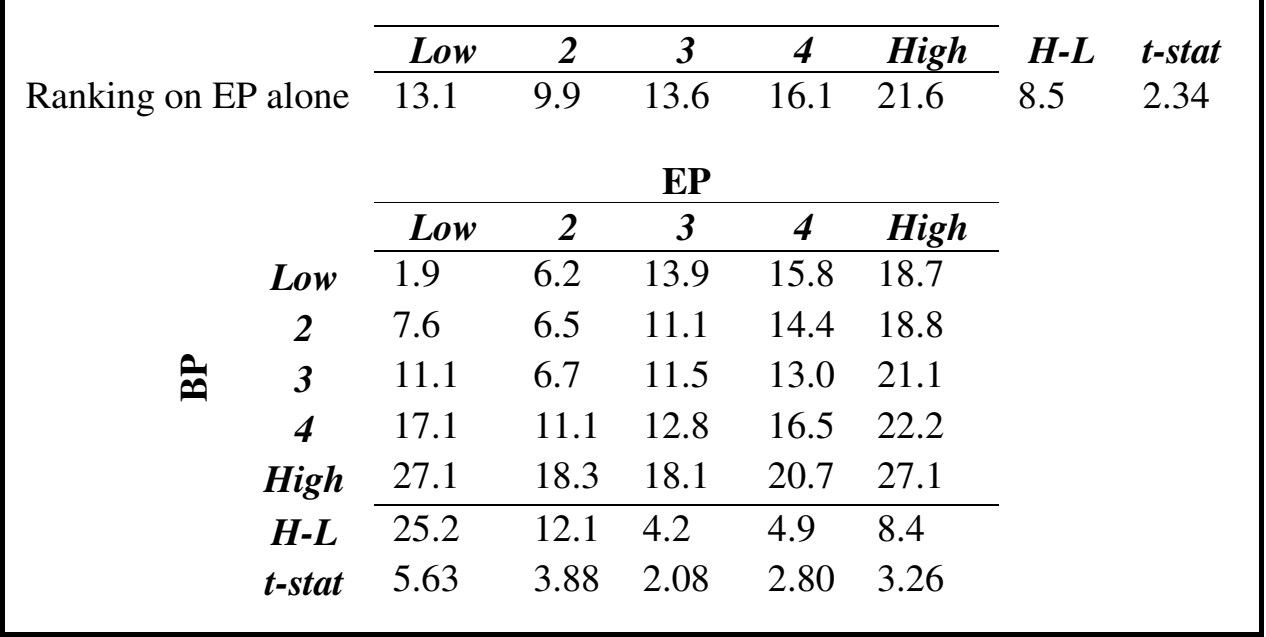

B. Mean Returns (in Percent) for Value-weighted Portfolios

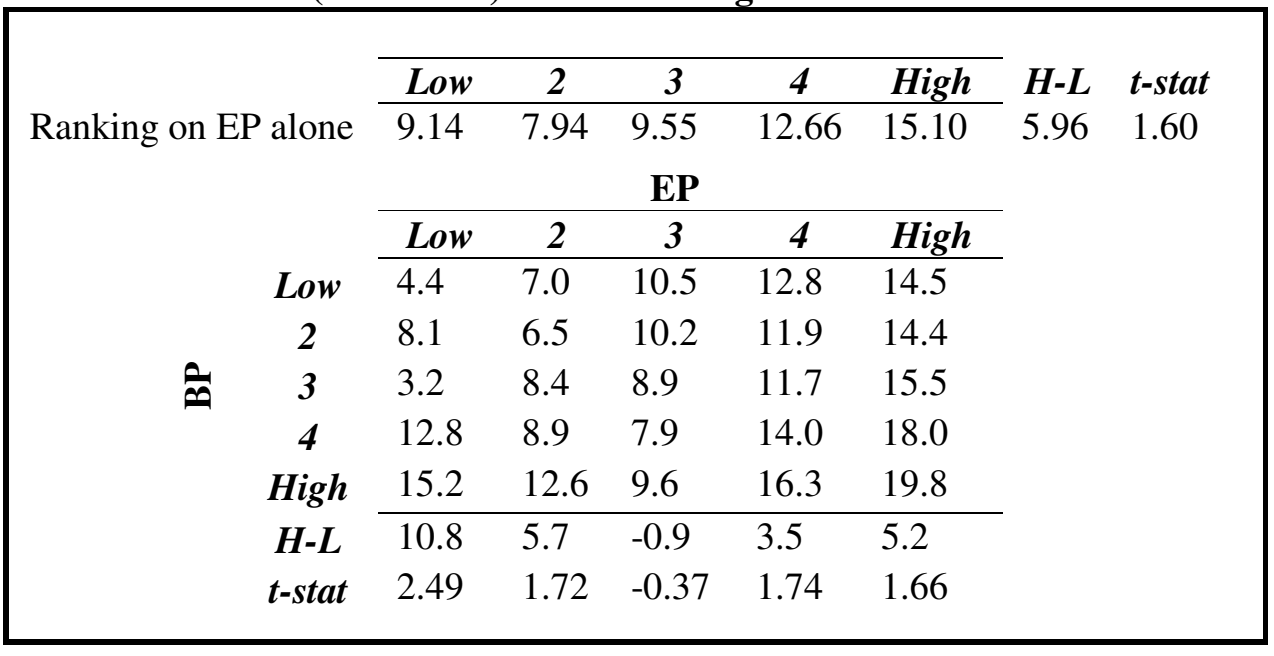


Table 2. Mean Earnings Growth Rates Two Years Ahead (\%) for Portfolios Formed by Ranking Firms Each Year on E/P and B/P, 1963-2015

The table reports the mean of median earnings growth rates two years ahead for the same portfolios as in Table 1. Earnings growth rates are calculated as $\frac{\text { Earning }_{t+2}-\text { Earning }_{t+1}}{\left(\mid \text { Earnings }_{t+2}|+| \text { Earnings }_{t+1} \mid\right) / 2}$ (in percent). This growth rate accommodates small and negative denominators, and ranges between 2 and -2 . For each portfolio in each year of the sample period, the median two-year ahead realized growth rate is calculated, with the mean over years then reported in the table.

\begin{tabular}{|c|c|c|c|c|c|c|c|}
\hline \multirow[b]{3}{*}{ Ranking on EP alone } & & & & & & \multirow{12}{*}{$\begin{array}{c}\boldsymbol{H}-\boldsymbol{L} \\
-38.2\end{array}$} & \multirow{4}{*}{$\begin{array}{l}\text { t-stat } \\
-17.22\end{array}$} \\
\hline & Low & 2 & 3 & 4 & High & & \\
\hline & 29.2 & 4.8 & -1.5 & -3.4 & -9.0 & & \\
\hline \multirow{9}{*}{$\hat{0}$} & \multicolumn{5}{|c|}{ EP } & & \\
\hline & Low & 2 & 3 & 4 & High & & \\
\hline & 17.5 & -3.6 & -4.5 & -7.6 & -12.5 & & \\
\hline & 23.9 & 0.1 & -5.5 & -5.0 & -9.7 & & \\
\hline & 29.4 & 3.7 & -3.0 & -2.8 & -9.8 & & \\
\hline & 33.9 & 5.8 & -2.3 & -2.9 & -9.4 & & \\
\hline & 41.0 & 16.9 & 7.2 & -0.5 & -5.8 & & \\
\hline & 23.5 & 20.5 & 11.7 & 7.1 & 6.7 & & \\
\hline & 6.49 & 5.90 & 3.88 & 2.61 & 1.98 & & \\
\hline
\end{tabular}


Table 3. Standard Deviation and Interdecile Range (IDR) of Realized

Earnings-to-Price One Year Ahead and Realized Earnings Growth Rates Two Years Ahead for Portfolios Formed by Ranking Firms on E/P and B/P; 19632015

The table documents the fundamental risk that the investor faces in investing in the E/P, B/P portfolios in Table 1. Panels A and B report the standard deviation and interdecile range of realized portfolio earnings one year ahead (relative to the current price), calculated from the time series of portfolio earnings over the sample period. Panels $\mathrm{C}$ and $\mathrm{D}$ report the same statistics for realized earnings growth rates two years ahead. Earnings growth rates are calculated as in Table 2 .

A. Standard Deviation of Portfolio Realized Earnings $s_{1} / P_{0}(\%)$

$$
\begin{aligned}
& \begin{array}{lrrrrrr}
\cline { 2 - 5 } \text { Ranking on EP alone } & \multicolumn{1}{c}{\text { Low }} & \mathbf{2} & \mathbf{3} & \mathbf{4} & \text { High } & \text { H-L } \\
\cline { 2 - 5 } & 10.0 & 5.0 & 3.7 & 4.1 & 5.0 & -5.0
\end{array}
\end{aligned}
$$

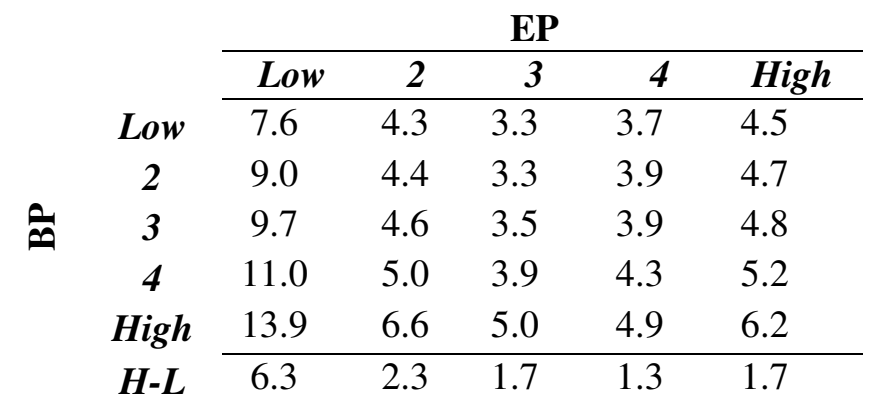

B. Interdecile Range (IDR) of Portfolio Realized Earnings $1 / P_{0}(\%)$

\begin{tabular}{|c|c|c|c|c|c|c|c|}
\hline \multirow{2}{*}{\multicolumn{2}{|c|}{ Ranking on EP alone }} & Low & 2 & 3 & 4 & High & \multirow{10}{*}{$\begin{array}{c}H-L \\
-9.8\end{array}$} \\
\hline & & 23.0 & 11.6 & 10.3 & 10.5 & 13.17 & \\
\hline \multirow{8}{*}{$\frac{\theta}{n}$} & & \multicolumn{5}{|c|}{ EP } & \\
\hline & & Low & 2 & 3 & 4 & High & \\
\hline & Low & 18.9 & 10.4 & 8.6 & 9.6 & 12.2 & \\
\hline & 2 & 21.7 & 10.9 & 8.7 & 10.2 & 12.3 & \\
\hline & 3 & 21.9 & 11.8 & 9.7 & 10.5 & 14.0 & \\
\hline & 4 & 25.5 & 11.6 & 10.8 & 11.3 & 13.4 & \\
\hline & High & 32.7 & 16.6 & 13.6 & 11.3 & 16.1 & \\
\hline & $H-L$ & 13.8 & 6.2 & 5.0 & 1.7 & 3.8 & \\
\hline
\end{tabular}


C. Standard Deviation of Realized Earnings Growth Two Years Ahead (\%)

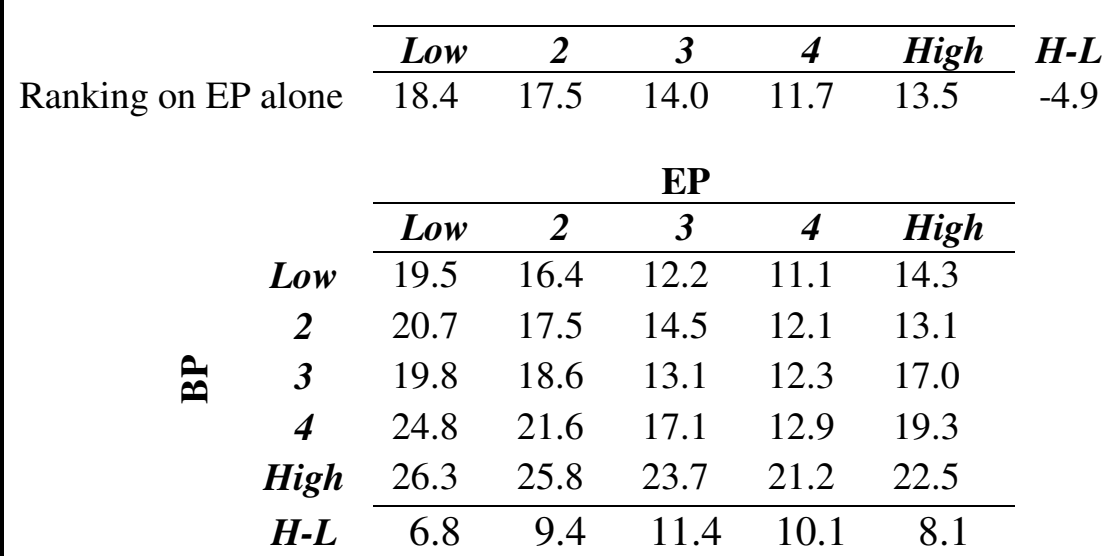

Corr with return

$\begin{array}{llllll}\text { standard deviation } & 0.87 & 0.54 & 0.65 & 0.75 & 0.81\end{array}$

D. Interdecile Range (IDR) of Realized Earnings Growth Rates Two Years Ahead (\%)

\begin{tabular}{|c|c|c|c|c|c|c|c|}
\hline \multicolumn{2}{|c|}{ Ranking on EP alone } & $\frac{\text { Low }}{438}$ & $\frac{2}{410}$ & $\frac{3}{356}$ & $\frac{4}{315}$ & $\frac{\text { High }}{209}$ & $\begin{array}{l}H-L \\
130\end{array}$ \\
\hline \multirow{8}{*}{$\hat{\theta}$} & & \multicolumn{5}{|c|}{ EP } & \\
\hline & & Low & 2 & 3 & 4 & High & \\
\hline & Low & 41.9 & 35.9 & 29.6 & 26.8 & 40.5 & \\
\hline & 2 & 48.7 & 44.1 & 30.3 & 28.5 & 28.0 & \\
\hline & 3 & 50.7 & 37.6 & 32.9 & 33.2 & 44.2 & \\
\hline & 4 & 61.1 & 55.3 & 42.8 & 33.2 & 45.4 & \\
\hline & High & 65.6 & 60.8 & 56.7 & 51.1 & 59.8 & \\
\hline & $H-L$ & 23.7 & 25.0 & 27.1 & 24.3 & 19.3 & \\
\hline
\end{tabular}


Table 4. Unconditional Earnings Betas and Up-market and Down-market Earnings Betas for Portfolios Formed by Ranking Firms on E/P and B/P; 1963-2015

The table reports (fundamental) earnings betas from regressing realized portfolio earnings yields in the time series on the aggregate market earnings yield. Panel A reports these betas over all conditions and Panels B and C report the betas in up-markets and down-markets respectively.

A. Unconditional Betas

\begin{tabular}{|c|c|c|c|c|c|c|}
\hline \multirow{8}{*}{$\hat{\theta}$} & & \multicolumn{5}{|c|}{ EP } \\
\hline & & Low & 2 & 3 & 4 & High \\
\hline & Low & 1.53 & 0.82 & 0.70 & 0.76 & 1.02 \\
\hline & 2 & 1.84 & 0.88 & 0.69 & 0.84 & 1.08 \\
\hline & 3 & 2.06 & 0.92 & 0.76 & 0.81 & 0.88 \\
\hline & 4 & 1.78 & 1.02 & 0.77 & 0.97 & 1.26 \\
\hline & High & 4.30 & 1.34 & 1.07 & 1.02 & 2.39 \\
\hline & $H-L$ & 2.78 & 0.52 & 0.38 & 0.27 & 1.37 \\
\hline
\end{tabular}

B. Up-market Betas

\begin{tabular}{|c|c|c|c|c|c|c|}
\hline \multirow{8}{*}{$\theta$} & & \multicolumn{5}{|c|}{ EP } \\
\hline & & Low & 2 & 3 & 4 & High \\
\hline & Low & 1.25 & 0.83 & 0.76 & 0.85 & 1.24 \\
\hline & 2 & 1.62 & 0.91 & 0.76 & 0.92 & 1.23 \\
\hline & 3 & 1.66 & 0.91 & 0.85 & 0.90 & 1.01 \\
\hline & 4 & 1.45 & 1.04 & 0.83 & 1.05 & 1.40 \\
\hline & High & 2.41 & 1.17 & 1.01 & 0.96 & 1.40 \\
\hline & $H-L$ & 1.17 & 0.35 & 0.25 & 0.10 & 0.16 \\
\hline
\end{tabular}

C. Down-market Betas

\begin{tabular}{|ccccccc|}
\hline & \multicolumn{5}{c}{ EP } \\
\cline { 2 - 6 } & Low & Low & $\mathbf{2}$ & $\mathbf{3}$ & $\mathbf{4}$ & High \\
\cline { 2 - 6 } & 1.42 & 0.67 & 0.50 & 0.45 & 0.70 \\
$\mathbf{2}$ & 1.71 & 0.66 & 0.51 & 0.64 & 0.91 \\
$\mathbf{3}$ & 2.03 & 0.71 & 0.53 & 0.57 & 0.76 \\
$\mathbf{4}$ & 1.71 & 0.68 & 0.51 & 0.75 & 0.99 \\
& High & 5.02 & 1.08 & 0.77 & 0.79 & 3.15 \\
\cline { 2 - 6 } & H-L & 3.60 & 0.41 & 0.27 & 0.34 & 2.45 \\
& & & & & \\
\hline
\end{tabular}




\section{Table 5. Annual Returns in Two Recent Down Markets, for Portfolios}

Formed by Ranking Firms Each Year on E/P and B/P

The table reports returns for the same portfolios as in Table 1, but for the two years with the lowest market returns in the last ten years of the sample period. In 2015, the S\&P 500 returned $1.38 \%$ and in $2008-37.0 \%$.

A. Portfolio Returns, April 2015 - March 2016 for Firms with Fiscal Year Ending December 31, 2014

\begin{tabular}{rrcccc} 
& \multicolumn{5}{c}{ EP } \\
\cline { 2 - 6 } Low & Low & $\mathbf{2}$ & $\mathbf{3}$ & $\mathbf{4}$ & High \\
\cline { 2 - 6 } & -37.5 & -23.3 & -8.6 & 2.9 & -14.3 \\
$\mathbf{2}$ & -36.5 & -29.4 & 0.0 & -6.3 & -8.5 \\
$\mathbf{3}$ & -26.6 & -22.1 & -1.2 & 0.1 & -5.8 \\
$\mathbf{4}$ & -23.9 & -13.3 & -9.5 & -1.9 & -16.7 \\
High & -28.3 & -16.1 & -13.2 & -5.6 & -26.9 \\
\cline { 2 - 6 } $\boldsymbol{H - L}$ & 9.2 & 7.3 & -4.5 & -8.4 & -12.6
\end{tabular}

B. Portfolio Returns, April 2008 - March 2009 for Firms with Fiscal Year Ending December 31, 2007

\begin{tabular}{rrrrrrr} 
& \multicolumn{5}{c}{ EP } \\
\cline { 2 - 6 } & Low & -46.9 & -42.5 & -32.8 & -36.8 & -36.9 \\
\cline { 2 - 6 } & $\mathbf{2}$ & -46.0 & -39.4 & -38.6 & -34.6 & -46.6 \\
$\mathbf{3}$ & -46.1 & -38.1 & -34.0 & -32.5 & -41.4 \\
$\mathbf{4}$ & -45.5 & -44.9 & -33.3 & -35.3 & -34.8 \\
High & -57.9 & -57.8 & -44.5 & -38.9 & -44.0 \\
\cline { 2 - 6 } $\boldsymbol{H}-\boldsymbol{L}$ & -11.0 & -15.3 & -11.7 & -2.1 & -7.1
\end{tabular}




\section{Table 6. Results by Size Quintiles, Including Weights on E/P and B/P for Forecasting Forward Returns}

For five size quintiles, the table reports $\mathrm{E} / \mathrm{P}$ and $\mathrm{B} / \mathrm{P}$ return spreads and estimated weights for fitting $\mathrm{E} / \mathrm{P}$ and $\mathrm{B} / \mathrm{P}$ to forward returns such that $R_{t+1}=w_{1} \frac{E_{t}}{P_{t}}+w_{2} \frac{B_{t}}{P_{t}}$. The table also reports ROE, earnings growth, and measures of the risk in growth, for the quintiles.

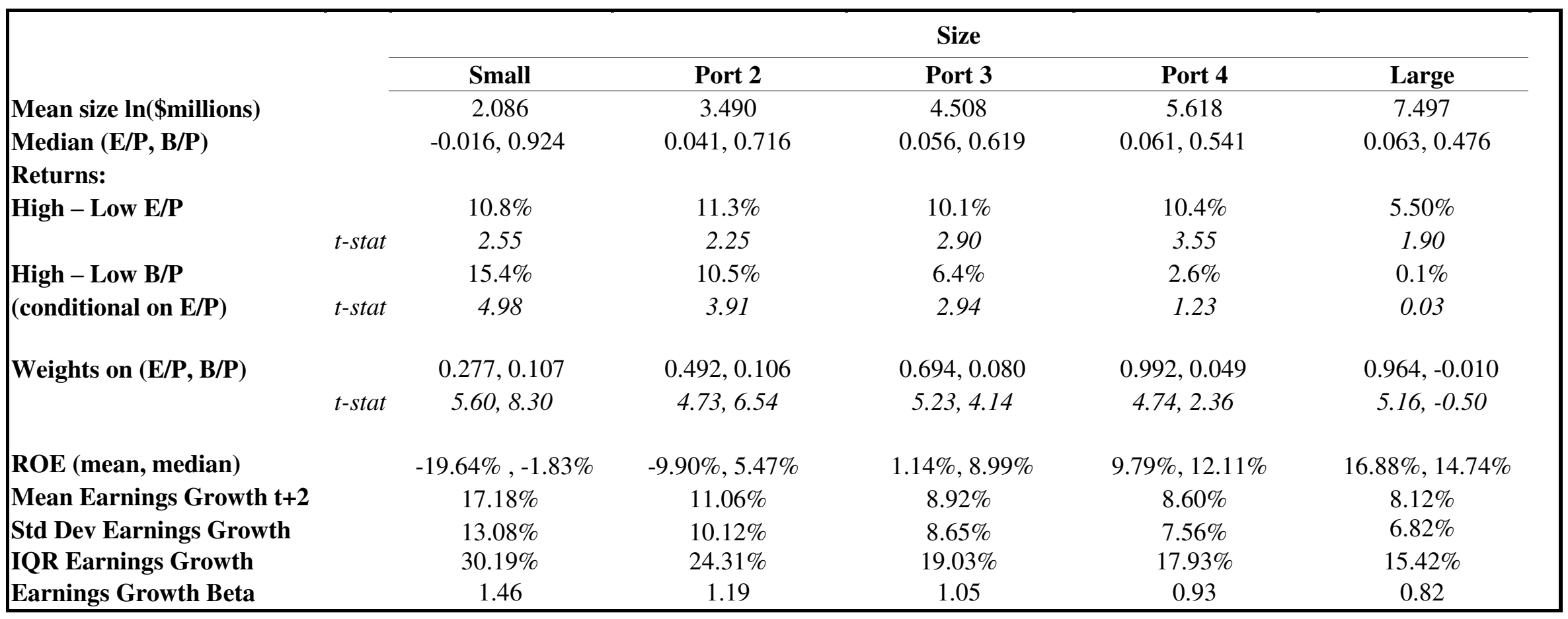

